\title{
Dynamics of regeneration of striated muscles in rats with posttraumatic reflex contractures
}

\author{
U.D. Matolych, V.V. Pankevych, S.V. Ushtan \\ Danylo Halytsky Lviv National Medical University, Ukraine; e-mail: ulyanam23@gmail.com
}

\begin{abstract}
In the comparative aspect the regeneration processes of striated muscles of hind left leg were researched in rats with posttraumatic reflex contractures against the background of physiotherapeutic treatment. Macroscopic and microscopic evaluation of pathomorphological changes has been conducted in this work. A relative area of myogenic elements (striated muscle elements), connective-tissue elements and neovasculature in the muscular-connective tissue in the scar in percentage has been determined using the method of point counting (field method). Depending on the signs of pain behavior (behavioral changes, additional signs), the intensity of myogenic pain syndrome (low, moderate, high, very high) has been studied. It has been established that the use of magnetic-laser therapy led to the formation of muscular-connective tissue scar up to the $28^{\text {th }}$ day with a predominance of a portion of striated muscle tissue of $90.74 \pm 0.17 \%$. Behavioral and motor responses became normalized; no pain was observed in $56 \%$ of rats, pain intensity was low in $44 \%$. In animals with the same trauma that were not treated, the portion of striated muscle tissue was $37.08 \pm 0.34 \%$, and signs of pain of high and moderate intensity were observed. By the $28^{\text {th }}$ day, the animals could brace against their hind limbs while moving, but due to a sharp restriction of the function of the left hind limb, they could not move freely. The obtained results are the basis for developing new approaches to improving the methods of remedial treatment of contractures using magnetic-laser therapy.

Key words: striated muscles; posttraumatic reflex contractures; magnetic-laser therapy.
\end{abstract}

\section{INTRODUCTION}

In connection with the increasing number of patients with traumatic damages of the maxillofacial area, settlement of problems arising during remedial treatment of posttraumatic reflex contractures of masticatory muscles remains relevant $[1,2]$. Muscles of the masticatory apparatus of a human include the $\mathrm{m}$. pterygoideus medialis. This muscle has a rich blood supply. The arteries are intramuscularly divided into branches of the 4-5 order and form a dense network of homocladic and heterocladic anastomoses by type end-to-end and end-toside. Such a dense network of anastomoses can be traumatized with a subsequent formation of hematoma, provided the muscle is injured with an injection needle [3]. Assuming that the damaging agent is not an injection needle, but a blow, or fractures of the lower jaw, the mechanism of development of posttraumatic and postinjection contractures of masticatory muscles is similar. The m.gastrocnemius of rats has the same striated structure as the human medial pterygoid muscle, so it has been chosen by us for the purpose of further simulation of the reflex contracture [4-7].

The use of physiotherapeutic treatments that have a corrective effect on the course of acute inflammatory reaction and the process of scarring, reduces the risk of development of cicatricial contracture of masticatory muscles. The presence of scar, which consists predominantly of connective tissue, cannot ensure a full function of the muscle as an organ [8-11].

The objective of the research was to study the dynamics of regeneration of striated muscles with posttraumatic reflex contractures against the background of physiotherapeutic treatment of laboratory rats. 


\section{METHODS}

The study was performed on 65 white outbred male rats 12 months of age with a weight of 180-200 g. Reflex posttraumatic muscle contractures (traumatic myositis) were simulated on the hind left legs, which arose as a result of the bruise of gastrocnemius muscles (without disturbing the integrity of muscular tissue) by method Fedyachkin [12]. The rats were fixed in the restraining chair in the face-down position. Skin cover was depilated on the inner surface of the thigh without excessive traumatism. The gastrocnemius muscle was squeezed for $8 \mathrm{sec}-$ onds under ether anesthesia with the help of the Collin's Forceps until visible signs of hematoma formation in subcutaneous fat were observed.

The rats were divided into two groups. The $1^{\text {st }}$ group included 40 animals that did not receive treatment, wounds were healed by secondary intention. The $2^{\text {nd }}$ group -25 rats, who had magnetic-laser therapy procedures conducted on the affected hind left limb on the $2^{\text {nd }}$ day after traumatic muscle damage.

A standard portable diode laser with a magnetic nozzle "Lika-Therapist" (Ukraine) was used in the work. The most optimal scanninglability method for striated muscles has been applied at $10 \mathrm{~Hz}$ frequency, wavelength of red radiation $-658 \mathrm{~nm}$, emission power $-25 \mathrm{~mW}$. Exposure duration - 10 minutes, number of sessions -14 procedures, which were performed daily in due time (during lunch).

We have chosen magnetic-laser therapy (MLRT) due to the possibility of conducting the procedure by notouch, atraumatic way, without disturbing the integrity of the skin, which prevents the possibility of infection. The basis of the mechanism of action make the general laws of neurohumoral responses, which contribute to increasing the adaptive, compensation and protective abilities of the body [13]. Every day, all rats were examined; their general condition, appearance, nutritional activity, nature and phase of the process of injury healing were evaluated. Depending on signs of pain behavior (behavioral changes, additional signs), the intensity of the myogenic pain syndrome (low, moderate, high, very high) has been evaluated [14]. The rats were decapitated ( 8 animals) at $7,14,21,28^{\text {th }}$ day after injury to the limbs.

Gastrocnemius muscles were removed from the damaged limbs for macroscopic and microscopic evaluation of pathomorphological changes. For histological examination $\mathrm{m}$. gastrocnemius were fixed in $10 \%$ formalin solution, poured into paraffin blocks, cuts were made using a sliding microtome, stained with hematoxylin - eosin, Van Gieson's picrofuchsin. Morphometric examination was performed using the method of point counting (field method). A grid of 60 equidistant points of "zero thickness" was used [15]. Relative area of myogenic elements (striated muscle elements), connectivetissue elements and newly formed vessels in the muscular-connective tissue scar (or regenerate) were determined in percentage.

The studies were conducted in compliance with the provisions of the European Convention for the Protection of Vertebrate Animals used for Experimental and Other Scientific Purposes (Strasbourg, 1986), GLP (1981), Order of the Ministry of Health of Ukraine No. 281 dated 1 November 2000 "On Measures for Further Improvement of Organizational Standards of Work with the Use of Experimental Animals."

The $t$ Student criteria were applied for estimating possible differences between the two groups. The research results are shown as arithmetic average values and standard deviations $(\mathrm{M} \pm \mathrm{m})$.

\section{RESULTS AND DISCUSSION}

While studying the work by Odintsova [16], we concluded that studying the regeneration of damaged tissues is aimed, above all things, at solving the task of influence on the course of wound healing. The author investigated the reactive ultrastructural changes of cellular programmed differentiations and the typical processes of regenerative histogenesis in musculocutaneous 
wounds in case of cut mechanical and gun-shot injuries in the experiment, which helped us to clearly determine all phases of the wound process in case of trauma of the hind limb in rats. In our study, we used the Flecknell, Liles [14] method of assessment of the severity of pain syndrome in animals by monitoring changes in their overall behavioral activity (gentle handling of an animal with its injured limb, refusal of food and water) as a means of correction of analgesic schemes.

It was found that in case of traumatic damage of striated muscles, a pronounced acute inflammatory reaction developed, which was typical, nonspecific. In case of natural wound healing, in all cases there was intense formation of connective-tissue scars in the injured gastrocnemius muscles of the legs. Clinically, this was manifested in the formation of muscular contracture.

On the $7^{\text {th }}$ day, in the study of histologic specimen of the $1^{\text {st }}$ group, a massive polymorphcellular infiltration was detected, karyolysis and karyopyknosis were observed, and disturbed architectonics of newly formed striated muscle elements was

noted (Fig. 1, a). The processes of the scar formation occurred slowly, with a significant predominance of the amount of connective tissue elements. On the $14^{\text {th }}$ day, the development of regenerative processes of striated muscle tissue was only recorded in the peripheral zones of the defect: thin myosymplasts appeared, which penetrated to the center of the defect to a small depth (Fig. 1, b). By the $21^{\text {st }}$ day, the processes of forming of muscular-connective tissue scar finished. Myotubules and newly formed skeletal muscle elements were located predominantly in the peripheral regions and penetrated into the central zone to a slight depth. The number of new muscle elements in muscular connective-tissue scar increased slightly (Fig. 1, c). On the $28^{\text {th }}$ day, a significant destruction of tissues resulted in the formation of a scar with a predominance of connective tissue, where the functional activity of the vessels of the microcirculatory bloodstream was reduced. A small amount of new muscle elements in the connective tissue was mainly located in the peripheral zones of the defect (Fig.1, d).

The results obtained in this paper coincide with the data by Fediachkin [12], who studied morphological changes in muscular tissue damaged by injury, which we used for further generalization of diagnostic criteria for the viability of injured tissues.

Complete adynamia was visually observed in the animals of the $1^{\text {st }}$ group during the first 3 days. Intensity of the pain reaction was very high or high. Animals often licked their affected limbs, squeaked loudly when the affected areas where touched, and they showed increased aggression against other animals and the researcher when there were attempts to take them in hand and remove from the cage. These rats had lowered appetite and they drank little. There was a significant postraumatic edema, decreased motor activity of rats. Subsequently, there was a gradual restoration of motor functions of the left hind limbs, but the animals continued to "spare" their damaged limbs. On the $28^{\text {th }}$ day, the animals could brace against their hind limbs while moving, but due to a sharp restriction of the function of the left hind limb, they could not move freely.

On the $7^{\text {th }}$ day, in the study of histologic specimen of the $2^{\text {nd }}$ group, a significant number of vessels was found in the regenerate, most of which were expanded and filled with erythrocytes, indicating a good functional activity of vessels of the microcirculatory bloodstream (Fig. 2, a). On the $14^{\text {th }}$ day, muscle buds were found in zones of damage, around which a moderate amount of myoblasts was accumulated. The presence of myotubules at different stages of differentiation has been noted. A significant amount of newly formed vessels was located in the connective tissue (Fig. 2, b). On the $21^{\text {st }}$ day, inflammatory changes were mild, but still some vessels of intermuscular connective tissue were expanded and overflown with blood. In the connective tissue newly 
formed vessels were moderately expanded and filled with red blood cells (Fig. 2, c). The processes of scar formation finished on the $28^{\text {th }}$ day. In the newly formed striated muscle elements, the nuclei were located in the central part of the sarcoplasm. A moderate filling with blood of the stroma vessels of striated muscle tissue was detected in muscles (Fig. 2, d).

A decrease in motor activity and a moderate pain reaction was observed in animals of the second group on the $7^{\text {th }}$ day. There were no manifestations of aggression in their behavior. A posttraumatic edema was significantly less than that of animals in the first group. On the $14^{\text {th }}$ and

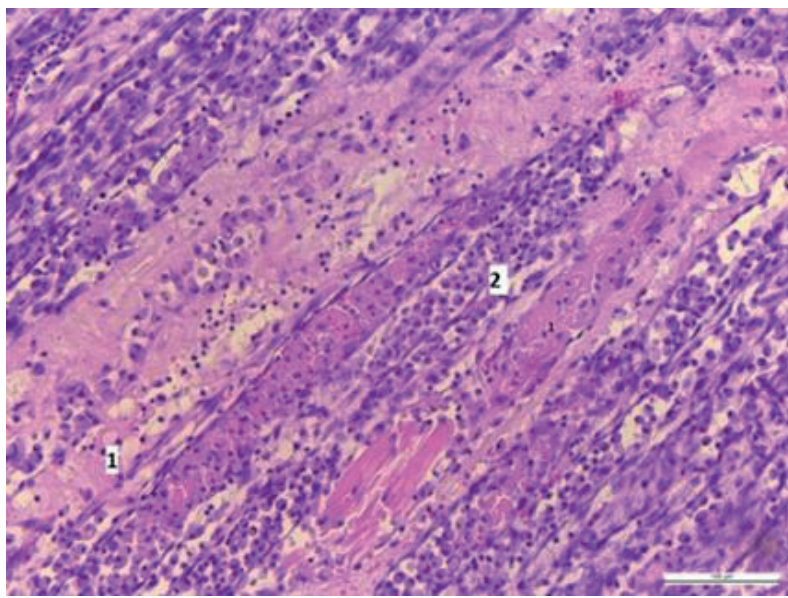

a

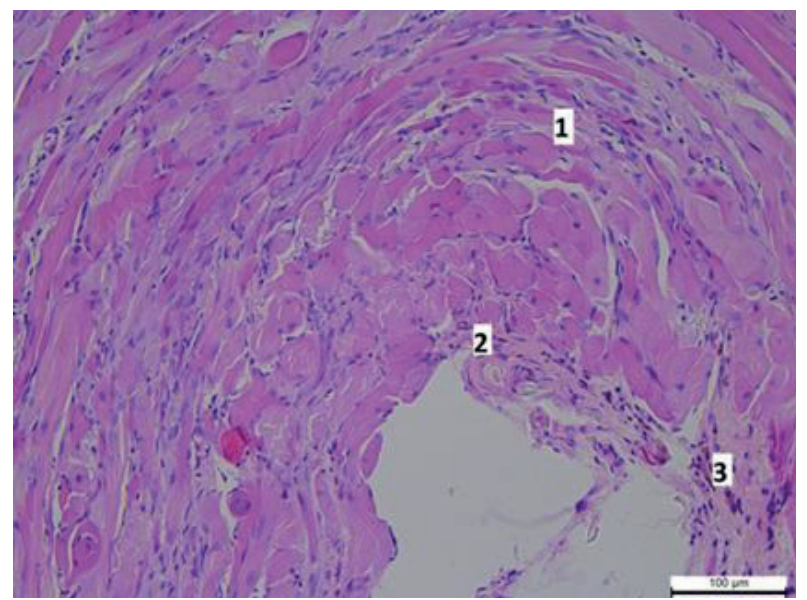

C $21^{\text {st }}$ day, there was a gradual restoration of the motor function of the hind left limbs. The rats braced against their damaged limb while moving and were hunched. On the $28^{\text {th }}$ day, rats had fully restored their motor activity.

The conducted studies revealed that during the first days after injury of the limbs, the structure of muscle fibers was significantly damaged. This manifested itself in a disturbed architectonics, fragmentation and aggregation in a conglomerate. There was a significant accumulation of exudate between the fibers, which was reflected in the edema of the endomysium. Vacuoles of various shapes and

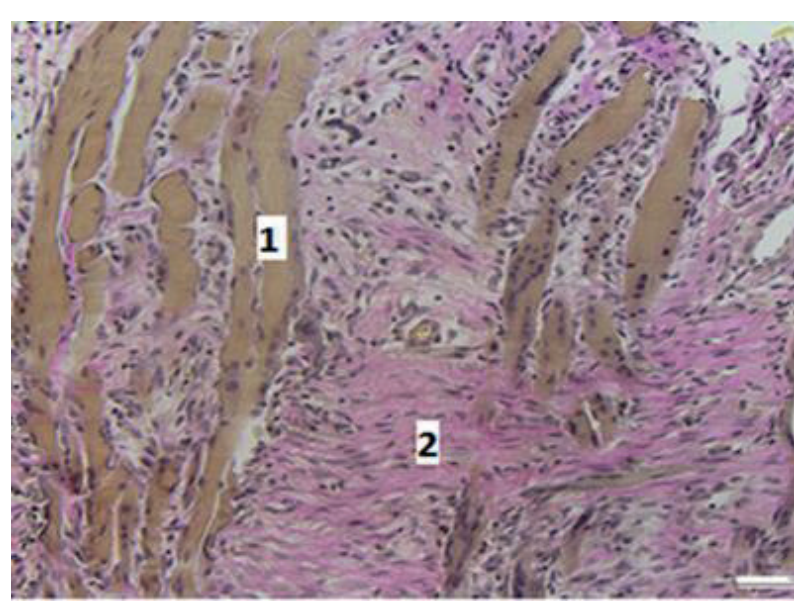

b

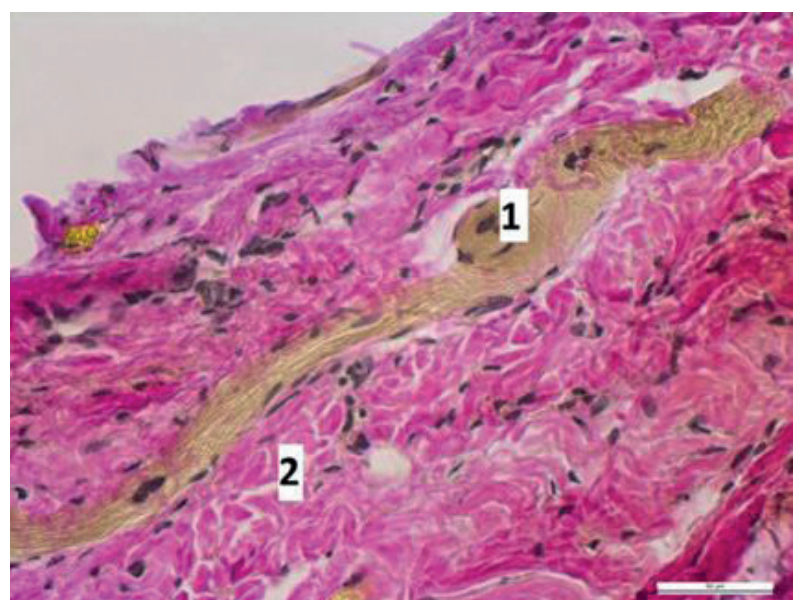

d

Fig. 1. Microphotographs of striated muscle of rats that did not receive treatment ( $1^{\text {st }}$ group): $a-$ on the $7^{\text {th }}$ day: $1-$ hlybchastyy posmuhovanyh disintegration of muscle fibers; 2 - accumulation of macrophages, neutrophils, lymphocytes; $b$ - on the $14^{\text {th }}$ day: 1 - miotuby; 2 - fibroblasts and collagen fibers; $\mathrm{c}$ - on the $21^{\text {st }}$ day 1 - muscle fibers; 2 - single capillaries; 3 -fibroblasty and collagen fibers; $\mathrm{d}$ - on the $28^{\text {th }}$ day: 1 - muscle fiber; 2 - fibroblasts and collagen fibers 


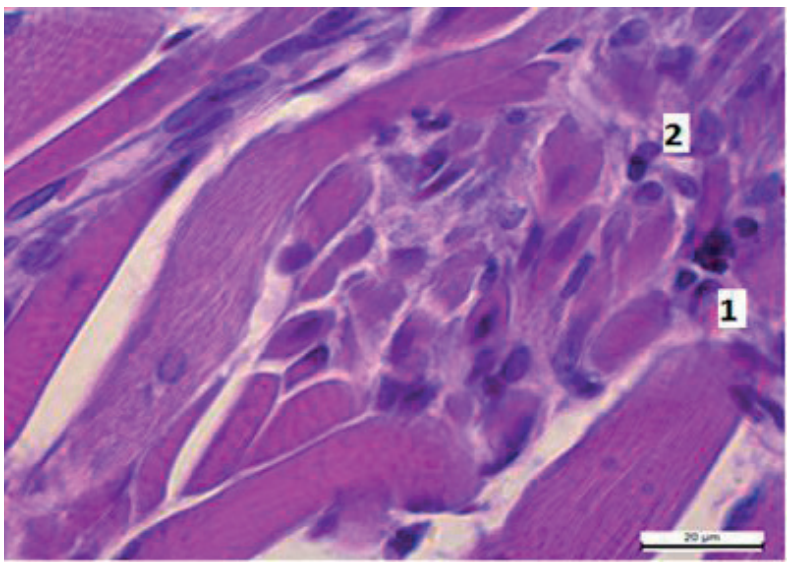

a

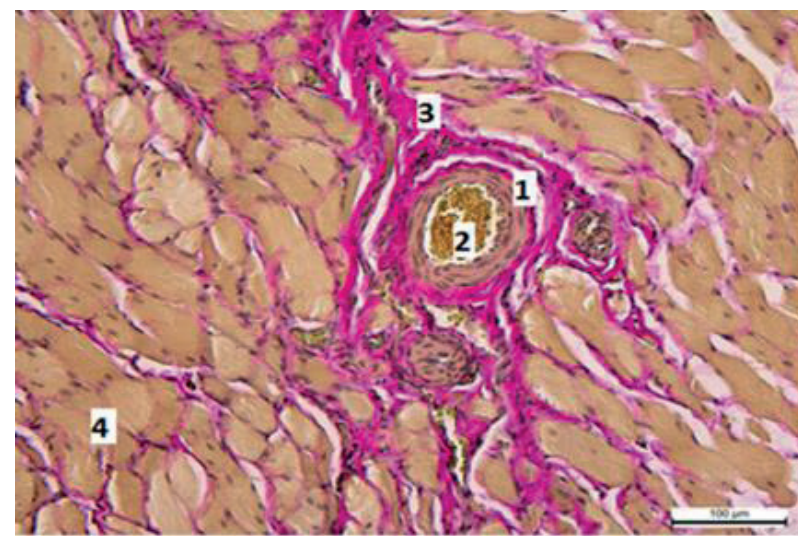

C

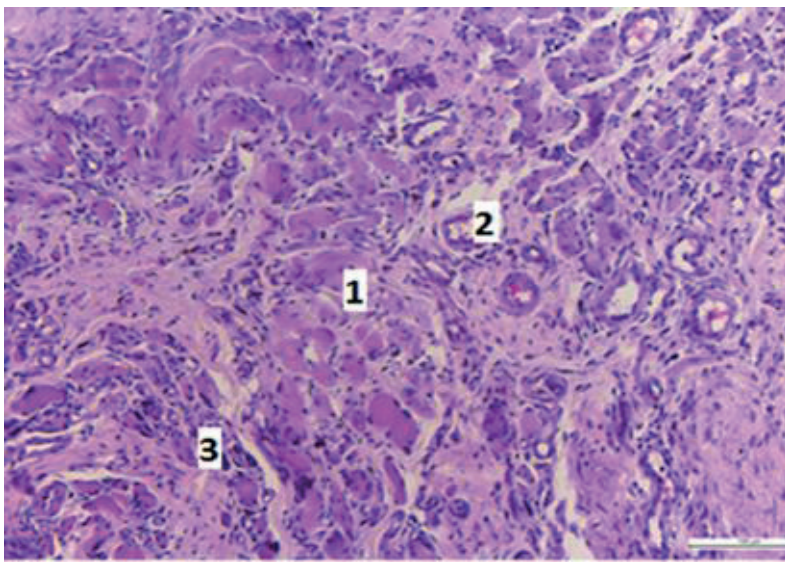

$\mathrm{b}$

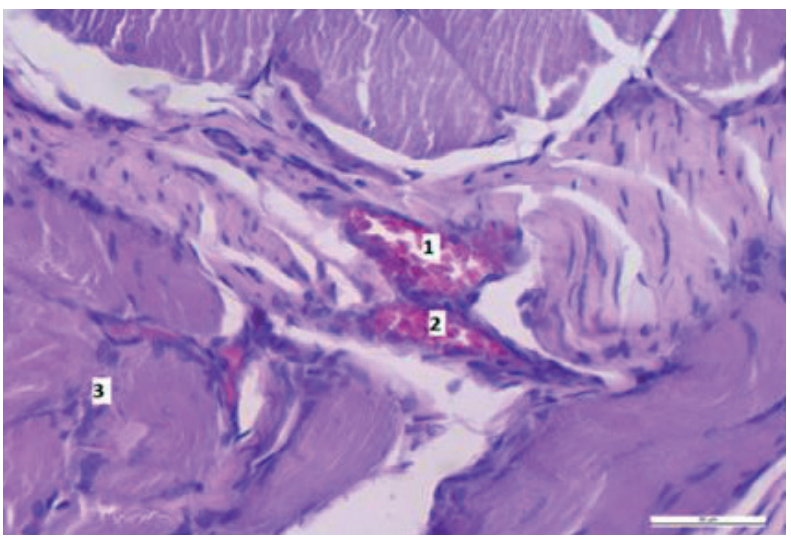

$\mathrm{d}$

Fig. 2. Microphotographs of muscles of rats that performed the procedures of magnetic-laser therapy ( $2^{\text {nd }}$ group): a - on the $7^{\text {th }}$ day: 1 - newly formed muscle fibers; 2 - neutrophilic granulocytes; $b$ - on the $14^{\text {th }}$ day: 1 - miotuby; 2 - capillary; 3 - fibroblasts; $\mathrm{c}$ - on the $21^{\text {st }}$ day: 1 - capillary; 2 - red blood cells; 3 - intramuscular connective tissue; 4 - muscle fibers; $d$ - on the $28^{\text {th }}$ day: 1 - capillary; 2 - red blood cells; 3 - muscle fibers

sizes appeared inside the fibers. Against the background of destructive changes in muscle fibers in the area of damage, there was a marked hemorrhage with significant contents of erythrocytes, leukocytes and macrophages. A muscular connective-tissue regenerate later formed on the site of damaged skeletal muscle tissue, the formation of which was completed by the $28^{\text {th }}$ day.

We found that the decrease in the intensity of pain syndrome depended on the sessions of magnetic-laser therapy. According to Zubkova's, Samosiuk's [9] data, laser therapy itself is an analgesic factor, and this effect is doubled in combination with a low-intensity magnetic field.
On the $7^{\text {th }}$ day, the intensity of the pain reaction in animals of the $1^{\text {st }}$ group remained high or very high, in the majority of animals of the $2^{\text {nd }}$ group - moderate.

The least pronounced changes in pain syndrome were recorded in animals of the $1^{\text {st }}$ group. On day 28, 13\% of rats showed signs of high intensity pain, $44 \%$ - signs of moderate pain, $22 \%$ - pain of low intensity. Only in $21 \%$ of rats we did not register any pain syndrome (Fig. 3, a).

The most pronounced decrease in the intensity of pain syndrome was recorded on the $28^{\text {th }}$ day in the $2^{\text {nd }}$ group: in $56 \%$ we did not register any pain syndrome, pain intensity 
was low in $44 \%$. There was a normalization of behavioral and motor reactions. The difference in the distribution of the rats of the two groups by the intensity of myogenic pain syndrome is likely to be significant (Fig. 3, b).

Analysis of the dynamics of the content of muscle elements showed: in the $1^{\text {st }}$ group the content of muscle fibers increased by 4.17 times on the $28^{\text {th }}$ day compared to the $7^{\text {th }}$ day and was $37.08 \pm 0.34 \%$, while in the $2^{\text {nd }}$ group - it grew by 8.22 and amounted to $90.74 \pm 0.17 \%$ $(\mathrm{P}<0.05)$. There was a probable decrease in the content of connective tissue, but in the $2^{\text {nd }}$ group it was more intense - by 9.68 times $(9.26 \pm 0.12$ $\%$ on the $28^{\text {th }}$ day) and in the $1^{\text {st }}$ group - by 1.44 $\left(62.92 \pm 0.26 \%\right.$ on the $28^{\text {th }}$ day).

Thus, a muscular-connective tissue scar with significant content of connective tissue elements (collagen fibers, fibroblasts) is formed in the animals of the $1^{\text {st }}$ group. A normotrophic scar with a significant increase in the elements of muscular tissue (muscle fibers) is formed in the animals of the $2^{\text {nd }}$ group. A morphometric study showed a direct dependence of the course of regeneration processes of striated muscles with posttraumatic reflex contractures on the conducted treatment.

We have found that against the use of MLRT there was a slowdown in the development of acute inflammatory reaction in the damaged muscular tissue of the hind limb of the animal, reparative processes accelerated and optimized, which prevented the excessive, functionally significant sclerosis.

\section{CONCLUSIONS}

1. Experimental-histological examination allowed to distinguish in the wound process the phase of traumatic necrosis, the phase of inflammation and the phase of regenerative histogenesis. The area of primary necrosis and
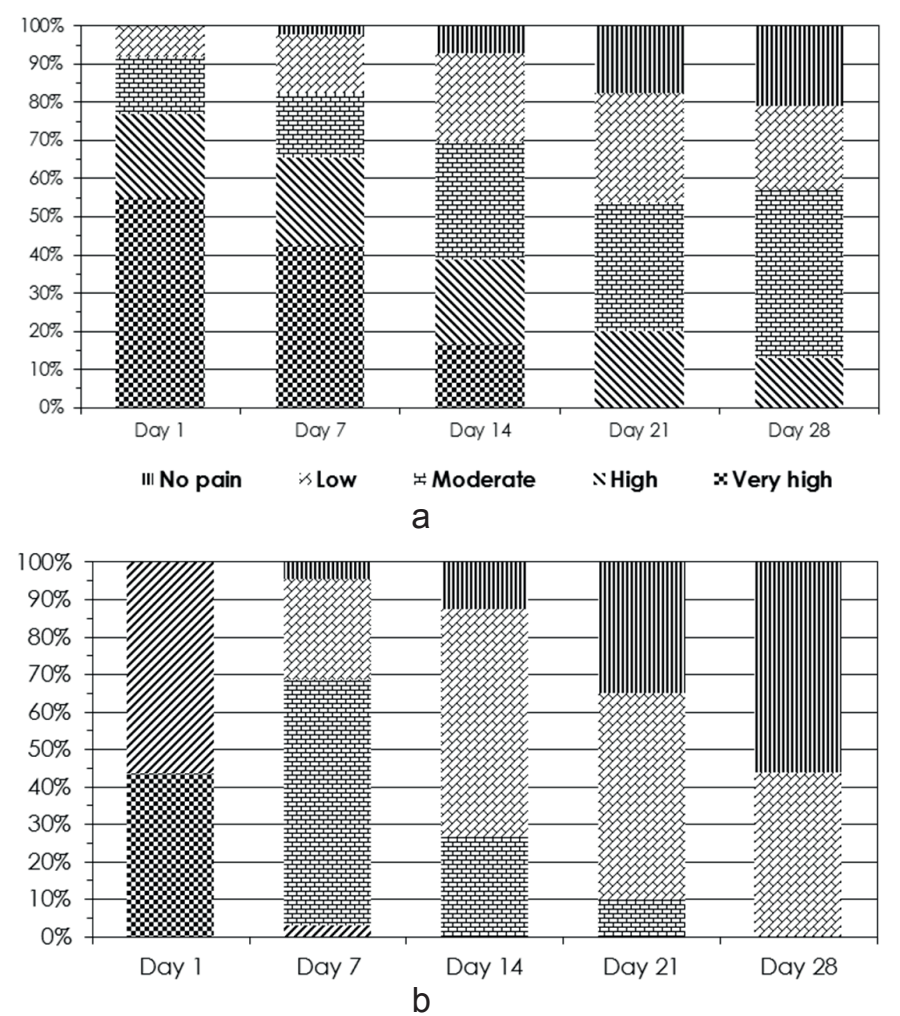

Fig. 3. The intensity of myogenic pain syndrome in rats with trauma of the m. gastrocnemius: a - rats that did not receive treatment ( $1^{\text {st }}$ group$) ; \mathrm{B}$ - rats that performed the procedures of magnetic-laser therapy $\left(2^{\text {nd }}\right.$ group $)$ 
areas, where the basic regular processes of regenerative histogenesis and stress shielding of tissue elements are manifested, are determined in tissues.

2 . It has been found that the use of magneticlaser therapy led to the formation of muscularconnective tissue scar by the $28^{\text {th }}$ day, with the predominance of the portion of striated muscle tissue in it $-90.74 \pm 0.17 \%$, connective tissue elements $-9.26 \pm 0.12 \%$. The animals with the same trauma that were not treated, a scar formed with significant content of connective tissue elements (collagen fibers, fibroblasts) $62.92 \pm 0.26 \%$, and the portion of striated muscle tissue was $37.08 \pm 0.34 \%$.

3 . The most pronounced reduction in pain intensity was recorded on the $28^{\text {th }}$ day in the group where treatment with magnetic-laser therapy was performed: $56 \%$ of the rats did not show any pain signs, $44 \%$ had a low pain intensity. Behavioral and motor responses were normalized.

4. It has been found that the use of MLRT has a multifactorial effect on the processes of reparative histogenesis of striated muscle tissue.

The authors of this study confirm that the research and publication of the results were not associated with any conflicts regarding commercial or financial relations, relations with organizations and/or individuals who may have been related to the study, and interrelations of co-authors of the article.

\section{У.Д. Матолич, В.В. Панькевич, С.В. Уштан}

ДИНАМІКА РЕГЕНЕРАЦІЇ ПОСМУГОВАНИХ М'ЯЗІВ У ЩУРІВ ІЗ ПІСЛЯТРАВМАТИЧНИМИ РЕФЛЕКТОРНИМИ КОНТРАКТУРАМИ

У порівняльному аспекті досліджували процеси регенерації посмугованих м'язів задньої лівої гомілки у щурів із післятравматичними рефлекторними контрактурами на тлі фізіотерапевтичного лікування. У роботі проведено макро- та мікроскопічну оцінку патоморфологічних змін. Визначено відносну площу міогенних елементів (посмугованих м'язових елементів), сполучнотканинних елементів та новоутворених судин у м'язово-сполучнотканинному рубці у відсотках за допомогою методу точкового підра- хунку (методу полів). Залежно від ознак больової поведінки (змін поведінки, додаткових ознак) вивчали інтенсивність міогенного больового синдрому (низький, помірний, високий, дуже високий). Встановлено, що використання магнітолазеротерапії призвело до формування до 28-ї доби м'язово-сполучнотканинного рубця з переважанням у ньому частки посмугованої м'язової тканини - 90,74士 0,17\%. Поведінкова та рухова реакції нормалізувались, у 56 \% щурів проявів болю не спостерігали, у $44 \%$ інтенсивність його була низькою. У тварин із такою самою травмою, яким не проводили лікування, частка посмугованої м'язової тканини була $37,08 \pm 0,34 \%$, спостерігали ознаки болю високої та помірної інтенсивності. На 28-му добу тварини могли спиратись на задні кінцівки під час переміщення, однак за рахунок різкого обмеження функції лівої задньої кінцівки їм не вдавалось повноцінно пересуватись. Отримані результати $є$ підставою для розробки нових підходів до удосконалення методів відновлювального лікування контрактур за допомогою магнітолазеротерапії. Ключові слова: посмуговані м'язи; післятравматичні рефлекторні контрактури; магнітолазеротерапія.

Львівський національний медичний університет ім. Данила Галииького, Україна; e-mail: ulyanam23@gmail.com

\section{У.Д. Матолич, В.В. Панькевич, С.В. Уштан}

\section{ДИНАМИКА РЕГЕНЕРАЦИИ ИСПОЛОСО- ВАННЫХ МЫШЦ У КРЫС С ПОСТТРАВМА- ТИЧЕСКИМИ РЕФЛЕКТОРНЫМИ КОНТРАКТУРАМИ}

В сравнительном аспекте исследовали процессы регенерации исполосованных мышц задней левой голени у крыс с посттравматическим рефлекторными контрактурами на фоне физиотерапевтического лечения. В работе проведено макро- и микроскопическую оценку патоморфологических изменений. Определенно относительную площадь миогенных элементов (исполосованных мышечных элементов), соединительнотканных элементов и новообразованных сосудов в мышечно-соединительнотканном рубце в процентах с помощью метода точечного подсчета (метода полей). В зависимости от признаков болевого поведения (изменений поведения, дополнительных признаков) изучали интенсивность миогенного болевого синдрома (низкий, умеренный, высокий, очень высокий). Установлено, что использование магнитолазеротерапии привело к формированию до 28-х суток мышечно-соединительнотканного рубца с преобладанием в нем доли

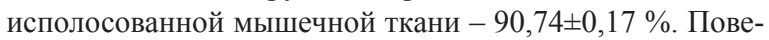
денческая и двигательная реакции нормализовались, у 56 \% крыс проявлений боли не наблюдали, у 44 \% интенсивность ее была низкой. У животных с такой же травмой, которым не проводили лечение, доля исполосованной мышечной ткани была $37,08 \pm 0,34$ \%, наблюдали признаки боли высокой и умеренной интенсивности. На 28-е сутки животные могли опираться на задние конечности при пе- 
ремещении, однако за счет резкого ограничения функции левой задней конечности им не удавалось полноценно передвигаться. Полученные результаты являются основанием для разработки новых подходов к совершенствованию методов восстановительного лечения контрактур с помощью магнитолазеротерапии.

Ключевые слова: исполосованные мышцы; посттравматические рефлекторные контрактуры; магнитолазеротерапия.

\section{REFERENCES}

1. Dydykin SS, Semkyn VA, Ibrahimov ZI. Topographicanatomical structure of the pterygo-mandibular space and its role in the development of postinjection contracture of the lower jaw. Reports Vinnytsia Nat Med Univ. 2006; 10(2): 325-6. [Ukrainian].

2. Matolych UD, Ushtan SV, Lapovets LYe, Horytskyy VM, Akimova VM. Dynamics of changes in humoral immunity in complicated and uncomplicated fractures of the lower jaw. Immun Allergol. 2009; 2-3: 150-1. [Ukrainian]

3. Tsyhykalo O. Topographical anatomy and operative surgery. Kiev: Naukova Dumka. 2011; 312. [Ukrainian].

4. Chemidronov SN, Gomoyunova SL, Pavlova IA, Gelashvily PA. The structural reorganization of blood microcirculation beds components in skeletal muscles of the rats after sectoral resection of the muscles venter. Morpholog Newsletter. 2007; 1-2: 144-7.

5. Makarov IV, Yamschikov NV, Makarova NV, Fedyatchkin AN. Morphological changes of skeletal muscular tissue and microcirculatory system in experimental atherosclerosis and hypergravitation environment. Morpholog Newsletter. 2007; 1-2: 76-80.

6. Stanishevskaya TI, Anosov IP. The influence of different thyroid status on electrophysiological and myographical parameters of skeletal muscles contraction in white rats. Fiziol Zh. 2016; 62(2): 57-63. [Ukrainian].

7. Eng CM, Smallwood LH, Rainiero MP, Lahey M, Ward SR, Lieber RL. Scaling of muscle architecture and fiber types in the rat hindlimb. J Exp Biol. 2008; 211: 2336-45.

8. Panto VI, Shymon VM. Laser radiation in clinical surgery. Cherkasy: Vertykal; 2010; 244. [Ukrainian].

9. Zubkova SM. Biophysical foundations of laser therapy. Rus J Physiotherapy, Balneol Rehabilit. 2009; 1: 3-9.

10. Samosiuk IZ, lyseniuk VP, loboda MV. Laser therapy and laser puncture in clinical and spa practice. Kiev: Health; 1997; 237. [Ukrainian].

11. Peixinho CC, Martins NS da F, de Oliveira LF, Machado JC. Reliability of Measurements of Rat Lateral Gastrocnemius Architectural Parameters Obtained from Ultrasound Biomicroscopic Images. PLOS ONE. 2014; 9(2): 691-4.

12. Fedyachkin AN, Makarov IV, Yamshchikov NV, Tulaeva ON. The effect of increased gravity on the state of skeletal muscle tissue and microcirculatory channel in conditions of experimental atherosclerosis. Health Edu Millennium. 2007; 3(9): 312-3.

13. Mokryk OJ, Nazarevich MR. Modern achievements in physiotherapy treatment of pain syndrome in patients with pathological processes in maxillofacial area. Med Hydro Rehabilit. 2012; 10(1): 19-23. [Ukrainian].

14. Flecknell PA, Liles JH. Evaluation of locomotor activity and food and water consumption as a method of assessing postoperative pain in rodents. Anim Pain. 1992; 1: 482-8.

15. Avtandilov GG. Medical morphometry. M: Medicine. $1990 ; 384$.

16. Odintsova IO. Histological criteria for healing of the cutaneous muscle injury in the experiment. Fundamental and applied problems of histology. Histogenesis and tissue regeneration. St.P.: MmedA. 2004; 257: 88-93. [Russian].

Received 13.06.2017 